Short Communication

\title{
Corrosion behavior of magnesium, aluminum and zinc as anodic materials in chloride based electrolytes for use in primary and secondary electrochemical power sources
}

\author{
B. Jugovića ${ }^{a}$, M. Gvozdenović ${ }^{b, *}$, J. Stevanovićc ${ }^{c}$, T. Trišovića ${ }^{a}$, B. Grgur ${ }^{b}$ \\ a ITS-Serbian Academy of Science and Arts, Knez Mihailova 35, Serbia \\ ${ }^{\mathrm{b}}$ Faculty of Technology and Metallurgy, University of Belgrade, Karnegijeva 4, Serbia \\ ${ }^{\mathrm{c}}$ ICTM-Institute of Electrochemistry, Njegoševa 12, Serbia
}

\section{A R T I C L E I N F O}

\section{Article history:}

Received 14 November 2008

Accepted 19 December 2008

Available online 27 December 2008

\begin{abstract}
A B S T R A C T
Corrosion behavior of magnesium, aluminum and zinc in $0.2 \mathrm{~mol} \mathrm{dm}^{-3} \mathrm{NH}_{4} \mathrm{Cl} ; 0.1 \mathrm{~mol} \mathrm{dm}^{-3} \mathrm{NH}_{4} \mathrm{Cl}$ with addition of $0.1 \mathrm{~mol} \mathrm{dm}^{-3} \mathrm{Na}$-citrate and corrosion behavior of zinc in $0.3 \mathrm{~mol} \mathrm{dm}^{-3} \mathrm{NH}_{4} \mathrm{Cl}$ with addition of $0.8 \mathrm{~mol} \mathrm{dm}^{-3} \mathrm{Na}$-citrate and different concentration of $\mathrm{ZnCl}_{2}$ were investigated. Corrosion current densities were determinated from the mass lost and from potentiodynamic $\left(1 \mathrm{mV} \mathrm{s}^{-1}\right)$ measurements. It was concluded that magnesium and aluminum are not suitable anodic materials for use in primary electrochemical power sources. On the other hand, it was concluded that zinc could be considered as possible anodic material in both primary and secondary electrochemical power sources.
\end{abstract}

(c) 2008 Elsevier Ltd. All rights reserved.

\section{Introduction}

Electrochemical power sources consisted of electroconducting polymers combined to electronegative metals and aqueous based electrolytes [1-6] are likely to accomplish most of the three E criteria: Energy (high energy content with respect to volume and weight), Economics (low manufacturing and maintenance costs, long service life), Environment (toxic free, safety, low energy consumption, easy to recycle) elaborated as the determining factors of an electrochemical power system success $[7,8]$. In such systems electroconducting polymers, mainly polyaniline (PANI) due to their ability of reversible oxidation (doping)/reduction (dedoping) could be used as cathodic materials, while owing to relatively low discharge potentials, it is necessary to use electronegative metals such as: magnesium, aluminum and zinc as anodic materials. Magnesium, owing to its very low electrode potential seems to be ideal anodic material for primary electrochemical power sources. The use of magnesium anode, in primary electrochemical power source based on PANI cathode, was investigated by Kumar et al. [9]. The main reason why magnesium was not commercialized as anodic material is intense corrosion in aqueous electrolytes.

Aluminum can also be considered as potentially useful anodic material for primary electrochemical power sources [10]. The use of aluminum anode and amalgamated aluminum in heavy duty chlorine-depolarized batteries with high open circuit voltage, were firstly reported by Heise et al. [11]. The aluminum/oxygen system

\footnotetext{
* Corresponding author.

E-mail address: popovic@tmf.bg.ac.rs (M. Gvozdenović).
}

was introduced by Zaromb [12] and Bockstie et al. [13] in the early sixties.. Unfortunately, all efforts made to commercially use aluminum in primary batteries failed, as a consequence of protective oxide film formation leading to decrease in cell voltage bellow theoretical value. The oxide film is also responsible for the time lag before the battery reaches its maximal operating voltage when the circuit is close (so-called delayed action) [10]. The problem with oxide film can be overcome by dissolution in concentrated alkaline solutions or by amalgamation, but these interventions are accompanied by accelerated corrosion.

Low price and high specific energy made zinc one of the most spread materials for primary and secondary electrochemical power sources. First attempts to develop aqueous based $\mathrm{Zn} \mid$ PANI were reported by Kitani et al. [14]. Trinidad et al. demonstrated similar electrochemical characteristics of such systems comparing to conventional batteries such as moderate energy density, good columbic efficacy and low self discharge [15]. Up to now Zn|PANI, despite their advantages have not been commercialized for few reasons. Apart from the fact that PANI electrode is degradable at potentials more positive than $0.5 \mathrm{~V}$ [16], the main reason is connected to zinc dendrite and solid phase formation during charge/discharge cycle [17], in chloride based electrolytes, affecting columbic efficacy and cycle life. It was shown that addition of citrate anions could prevent zinc dendrite formation, and that PANI electrode exhibited enhanced discharge characteristics $[18,19]$. The aim of this paper was to investigate corrosion and polarization behavior of magnesium, aluminum and zinc electrodes in chloride based electrolytes with addition of citrate, as possible anodic materials in primary and secondary electrochemical power sources based on PANI cathode. 


\section{Experimental}

Corrosion behavior of magnesium, aluminum and zinc, were determined by measuring the mass difference of metal (99.99 wt.\%) sheet simples $\left(S=16 \mathrm{~cm}^{2}\right)$ before and after immersion in chloride based electrolytes.

Potentiodynamic polarization curves were recorded, after $1 \mathrm{~h}$ of immersion, at scan rate $v=1 \mathrm{mV} \mathrm{s}^{-1}$ using PAR 263A potetntiostat interfered to PC. Three compartment electrochemical cell was used with aluminum and zinc $\left(S=2 \mathrm{~cm}^{2}\right)$ working electrodes. The counter electrode was platinum wire, while saturated calomel (SCE) electrode was used as reference electrode.

All experiments were performed at ambient temperature in solutions composed of: $0.2 \mathrm{~mol} \mathrm{dm}{ }^{-3} \mathrm{NH}_{4} \mathrm{Cl} ; 0.1 \mathrm{~mol} \mathrm{dm}^{-3} \mathrm{NH}_{4} \mathrm{Cl}$ with addition of $0.1 \mathrm{~mol} \mathrm{dm}^{-3} \mathrm{Na}$-citrate and $0.3 \mathrm{~mol} \mathrm{dm}^{-3} \mathrm{NH}_{4} \mathrm{Cl}$ with addition of $0.8 \mathrm{~mol} \mathrm{dm}^{-3} \mathrm{Na}$-citrate and different concentration of $\mathrm{ZnCl}_{2}, \mathrm{pH}$ value of all used electrolytes were $\sim 5$. Electrolytes were prepared using bidistilled water and p.a. grade chemicals (Merk).

Before corrosion and polarization measurements metal samples were first mechanically polished with fine emery papers $(2 / 0,3 / 0$ and $4 / 0$ ) and than with polishing alumina of $1 \mu \mathrm{m}$ (Banner Scientific Ltd.) on polishing cloths (Buehler Ltd.). After mechanical polishing the traces of the polishing alumina were removed in ultrasonic bath during $5 \mathrm{~min}$.

\section{Results and discussion}

3.1. Magnesium, aluminum and zinc as possible anodic materials for primary electrochemical power sources

First parameter to be discussed in proper choice of a metal to be used in an electrochemical power source is its corrosion in given electrolyte. Hence, corrosion of magnesium, aluminum and zinc in chloride and chloride/citrate solutions was investigated by measuring the mass difference of metal samples before and after immersion. The mean value of the corrosion current densities, $j_{\text {corr }}$, were determined according to Faradays law. The values of the corrosion potential, $E_{\text {corr }}$, and mean corrosion current density of magnesium, aluminum and zinc in $0.2 \mathrm{~mol} \mathrm{dm}^{-3} \mathrm{NH}_{4} \mathrm{Cl}$ and $0.1 \mathrm{~mol} \mathrm{dm}^{-3} \mathrm{NH}_{4} \mathrm{Cl}$ with addition of $0.1 \mathrm{~mol} \mathrm{dm}^{-3} \mathrm{Na}$-citrate are given in Table 1.

As it can be seen in Table 1, in both electrolytes magnesium had grates values of the corrosion current density, than followed zinc and aluminum. Comparison of the mean value of the corrosion current densities of each metal in chloride and chloride/citrate electrolytes is given in Fig. 1.

As it could bee observed in Fig. 1, the corrosion current density of magnesium and aluminum was practically independent on given electrolyte composition. However, the difference in corrosion current densities in chloride and chloride/citrate electrolyte is significant, namely the observed corrosion current density in chloride/citrate electrolyte was for almost one order of magnitude grater than in citrate electrolyte. Based on above presented results,

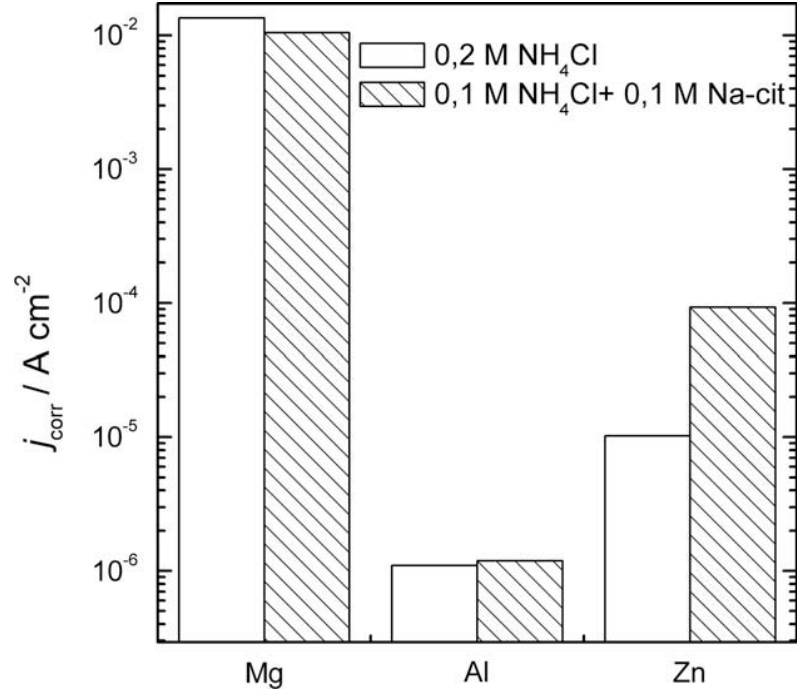

Fig. 1. Comparison of the corrosion current densities of $\mathrm{Mg}, \mathrm{Al}$ and $\mathrm{Zn}$ in $0.2 \mathrm{~mol} \mathrm{dm}^{-3} \mathrm{NH}_{4} \mathrm{Cl}$ and $\mathrm{NH}_{4} \mathrm{Cl}+0.1 \mathrm{~mol} \mathrm{dm}^{-3} \mathrm{Na}$-citrate.

it could be concluded that magnesium, aluminum and zinc were liable to corrosion in investigated electrolytes.

Upon immersion of magnesium in both citrate and citrate/chloride electrolyte, intense hydrogen evolution was observed, and after about ten minutes weak ammonia scent was developed. Based on the values of the corrosion potential of magnesium of $-1.889 \mathrm{~V}$ (SHE) in chloride and $-1.724 \mathrm{~V}$ (SHE) in chloride/citrate electrolyte, and according to Pourbaix diagrams [20], corrosion reaction of magnesium in chloride and chloride/citrate solutions could be explained by anodic dissolution of magnesium:

$\mathrm{Mg}=\mathrm{Mg}^{2+}+2 \mathrm{e}$

and cathodic hydrogen evolution:

$2 \mathrm{H}_{2} \mathrm{O}+2 \mathrm{e}=\mathrm{H}_{2}+2 \mathrm{OH}^{-}$

while observed ammonia evolution could be explained by reduction of ammonium ion, owing to negative electrode potential of magnesium, according to:

$2 \mathrm{NH}_{4}^{+}+2 \mathrm{e}=2 \mathrm{NH}_{3}+\mathrm{H}_{2}$

The increase in $\mathrm{pH}$ of the solution, as a result of hydrogen and ammonia co evolution, could change corrosion product of magnesium from $\mathrm{Mg}^{2+}$ to insoluble $\mathrm{Mg}(\mathrm{OH})_{2}$. Since that intense hydrogen evolution was observed followed by changes in $\mathrm{pH}$ of the solution, polarization curves of the magnesium electrode could not be recorded. However, due to very low corrosion potential, magnesium might be considered as potentially good anodic material for activated primary electrochemical power sources.

Aluminum, comparing to magnesium and zinc, had lowest values of the corrosion current density of around $1 \mu \mathrm{A} \mathrm{cm}^{-2}$ and highest value of the corrosion potential of around $-0.45 \mathrm{~V}$ (SHE) in both chloride and chloride/citrate solutions. According to Pourbaix dia-

Table 1

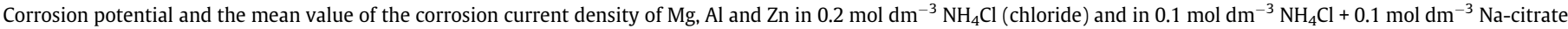
(chloride/citrate)

\begin{tabular}{|c|c|c|c|c|c|c|}
\hline \multirow[t]{2}{*}{ Metal } & \multicolumn{2}{|c|}{$E_{\text {corr }} / \mathrm{V}(\mathrm{SCE})$} & \multicolumn{2}{|c|}{$E_{\text {corr }} / \mathrm{V}(\mathrm{SHE})$} & \multicolumn{2}{|l|}{$j_{\text {corr }} / \mathrm{A} \mathrm{cm}^{-2}$} \\
\hline & Chloride & Chloride/citrate & Chloride & Chloride/citrate & Chloride & Chloride/citrate \\
\hline $\mathrm{Mg}$ & -2.130 & -1.965 & -1.889 & -1.724 & $1.35 \times 10^{-2}$ & $1.05 \times 10^{-2}$ \\
\hline $\mathrm{Al}$ & -0.705 & -0.688 & -0.464 & -0.447 & $1.10 \times 10^{-6}$ & $1.19 \times 10^{-6}$ \\
\hline $\mathrm{Zn}$ & -1.138 & -1.116 & -0.897 & -0.875 & $1.02 \times 10^{-5}$ & $9.27 \times 10^{-5}$ \\
\hline
\end{tabular}


gram and taking into account $\mathrm{pH} 5$, it could be concluded that aluminum was in its passive state $\left(\mathrm{Al}_{2} \mathrm{O}_{3}\right)$ at corrosion potential. Owing to the relatively high value of the corrosion potential, cathodic reaction could be oxygen evolution reaction:

$2 \mathrm{H}_{2} \mathrm{O}=4 \mathrm{H}^{+}+\mathrm{O}_{2}+4 \mathrm{e}$

According to the value of the corrosion potential in investigated electrolytes, aluminum is not challengeable anodic material for primary electrochemical power source based on polyaniline cathode. Potentiodynamic $\left(1 \mathrm{mV} \mathrm{s}^{-1}\right)$ anodic polarization curves of aluminum in chloride and chloride/citrate electrolytes were recorded and given in Fig. 2.

As it could be observed in Fig. 2, polarization curves were practically the same in both chloride and chloride/citrate electrolyte. Two values of anodic Tafel slopes of $\sim 40 \pm 0.2 \mathrm{mV} \mathrm{dec}^{-1}$ for chloride, $\quad 40 \pm 0.8 \mathrm{mV} \mathrm{dec}^{-1}$ for chloride/citrate at low and $\sim 125 \pm 0.6 \mathrm{mV} \mathrm{dec}^{-1}$ at high current densities, were obtained. For current densities of practical interest (higher than $1 \mathrm{~mA} \mathrm{~cm}^{2}$ ), potential of the aluminum electrode in both electrolytes was around $-0.55 \mathrm{~V}$ (SCE), e.g. $-0.3 \mathrm{~V}$ (SHE), meaning that aluminum could not be considered as anodic material in electrochemical power source based on PANI cathode.

As mentioned above, although the values of the corrosion potential of zinc in both chloride and chloride/citrate electrolyte were similar $\sim-0.88 \mathrm{~V}$ (SHE), corrosion current density in chloride/citrate electrolyte was for almost one order of magnitude grater than in citrate electrolyte and it could be probably connected to influence of citrate ions on mechanism of zinc dissolution. According to Pourbaix diagrams [20], it could be concluded that zinc was between stable metallic state and corrosion with formation of $\mathrm{Zn}^{2+}$.

Polarization curves of zinc electrode in citrate and citrate/chloride electrolytes are given in Fig. 3.

As it could be seen in Fig. 3 anodic polarization curves of zinc in citrate and citrate/chloride electrolytes were characterized by the same Tafel slope of $40 \pm 0.2 \mathrm{mV} \mathrm{dec}^{-1}$ at low current densities, while Tafel slopes of $90 \pm 0.2 \mathrm{mV} \mathrm{dec}^{-1}$ for chloride and $120 \pm 0.4 \mathrm{mV} \mathrm{dec}^{-1}$ for chloride/citrate were obtained for higher current densities, connected to zinc dissolution according to:

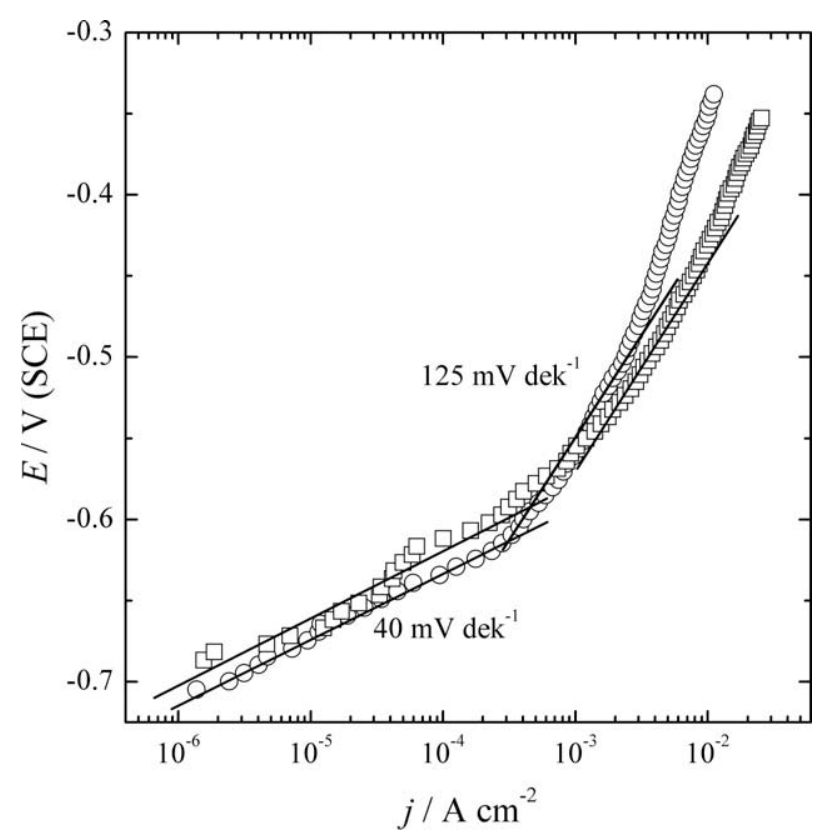

Fig. 2. Anodic polarization curve $\left(1 \mathrm{mV} \mathrm{s}^{-1}\right)$ of aluminum in: (O) $-0.2 \mathrm{~mol} \mathrm{dm} \mathrm{m}^{-3}$ $\mathrm{NH}_{4} \mathrm{Cl}$ and $(\square)-0.1 \mathrm{~mol} \mathrm{dm}^{-3} \mathrm{NH}_{4} \mathrm{Cl}+0.1 \mathrm{~mol} \mathrm{dm}{ }^{-3}$ Na-citrate.

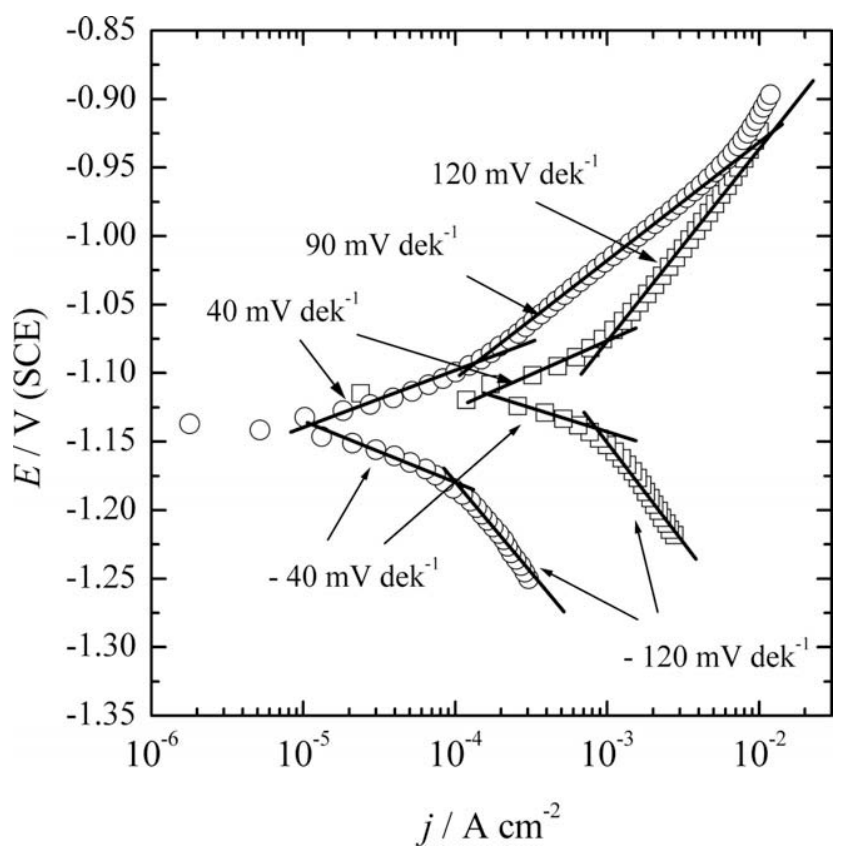

Fig. 3. Anodic and cathodic polarization curves $\left(1 \mathrm{mV} \mathrm{s}^{-1}\right)$ of zinc in: ( $\square$ ) $-0.2 \mathrm{~mol} \mathrm{dm}^{-3} \mathrm{NH}_{4} \mathrm{Cl}$ and $(\mathrm{O})-0.1 \mathrm{~mol} \mathrm{dm}^{-3} \mathrm{NH}_{4} \mathrm{Cl}+0.1 \mathrm{~mol} \mathrm{dm}^{-3}$ Na-citrate.

$\mathrm{Zn}=\mathrm{Zn}^{2+}+2 \mathrm{e}$

Cathodic polarization curves of zinc electrode in both chloride and chloride/citrate electrolytes were characterized by similar values of Tafel slopes of -40 and $-120 \mathrm{mV} \mathrm{dec}^{-1}$. Owing to low value of the corrosion potential, cathodic reaction of zinc electrode in both electrolytes, it could be assumed that cathodic reaction was hydrogen evolution given by reaction (2). Corrosion current densities of zinc in both electrolytes obtained from the intercept of anodic and cathodic polarization curves were practically the same as those obtained from the mass difference indicating uniform corrosion. As seen in Fig. 3, for current densities of practical interest (higher than $\left.1 \mathrm{~mA} \mathrm{~cm}^{2}\right)$, potential of the zinc electrodes were around -1.05 and $1.0 \mathrm{~V}$ (SCE), indicating that zinc could be used as anodic material in primary electrochemical power sources based on PANI cathode, such system would have discharge voltage around $1.2 \mathrm{~V}$.

\subsection{Zinc as possible anodic material for secondary electrochemical power sources}

Since that addition of zinc ions in electrolyte could crate conditions for the use of zinc electrode in secondary electrochemical power source, corrosion of zinc was investigated in solution consisted of $0.3 \mathrm{~mol} \mathrm{dm}^{-3} \mathrm{NH}_{4} \mathrm{Cl}$ and $0.8 \mathrm{~mol} \mathrm{dm}^{-3} \mathrm{Na}$-citrate with addition of $0.1 ; 0.3$ and $0.5 \mathrm{~mol} \mathrm{dm}{ }^{-3} \mathrm{ZnCl}_{2}$. The mean value of the corrosion current densities, $j_{\text {corr }}$, were determined according to Faradays law. The values of the open circuit potentials, $E_{\text {ocp}}$, and the mean corrosion current densities of zinc in investigated electrolytes are given in Table 2.

Table 2

Open circuit potential, corrosion current density and exchange current density of zinc in $0.3 \mathrm{~mol} \mathrm{dm}^{-3} \mathrm{NH}_{4} \mathrm{Cl}+0.8 \mathrm{~mol} \mathrm{dm}^{-3}$ Na-citrate with addition of $0.1 ; 0.2$ and $0.3 \mathrm{~mol} \mathrm{dm}^{-3} \mathrm{ZnCl}_{2}$.

\begin{tabular}{llll}
\hline$c\left(\mathrm{Zn}^{2+}\right) / \mathrm{mol} \mathrm{dm}^{-3}$ & $E_{\text {ocp }} / \mathrm{V}(\mathrm{SCE})$ & $j_{\text {corr }} / \mathrm{A} \mathrm{cm}^{-2}$ & $j_{0} / \mathrm{A} \mathrm{cm}^{-2}$ \\
\hline 0.1 & -1.180 & $0.92 \times 10^{-5}$ & $4.0 \times 10^{-4}$ \\
0.3 & -1.122 & $1.03 \times 10^{-5}$ & $5.0 \times 10^{-4}$ \\
0.5 & -1.094 & $4.96 \times 10^{-5}$ & $0.92 \times 10^{-3}$ \\
\hline
\end{tabular}




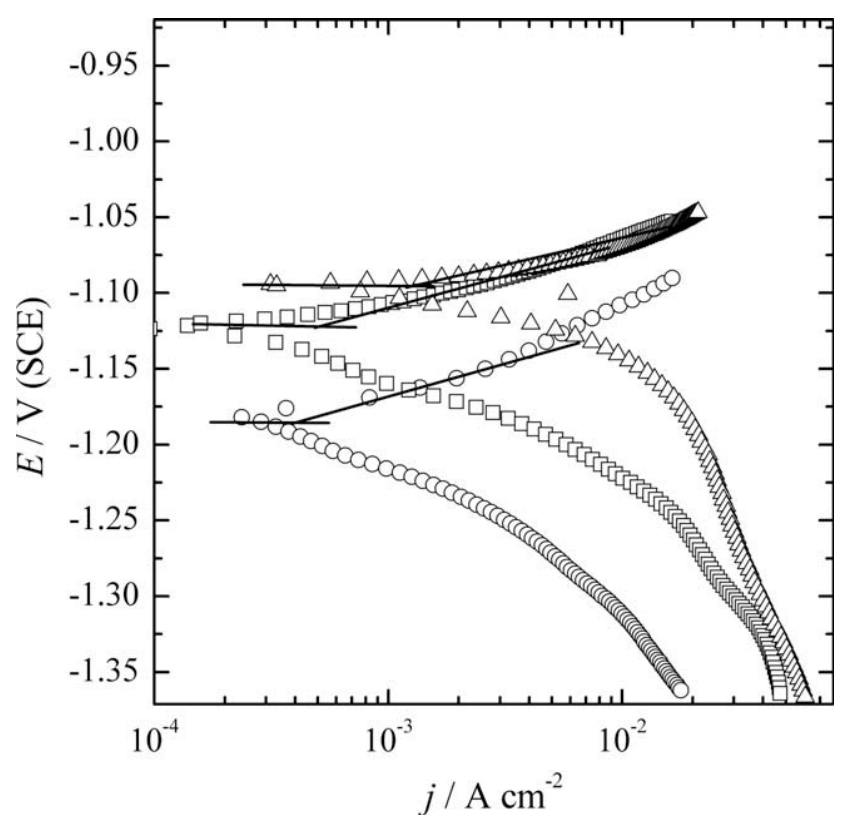

Fig. 4. Anodic and cathodic polarization curves $\left(1 \mathrm{mV} \mathrm{s}^{-1}\right)$ of zinc in $0.3 \mathrm{~mol} \mathrm{dm}^{-3}$ $\mathrm{NH}_{4} \mathrm{Cl}+0.8 \mathrm{~mol} \mathrm{dm}{ }^{-3} \mathrm{Na}$-citrate with addition of: $(\bigcirc)-0.1 ;(\square)-0.3$ and $(\triangle)$ $-0.5 \mathrm{~mol} \mathrm{dm}^{-3} \mathrm{ZnCl}_{2}$.

Polarization curves of zinc electrode in citrate/chloride electrolyte with addition of zinc ions are given in Fig. 4., while values of the exchange current densities obtained from the intercept of anodic Tafel slope with open circuit potential are given in Table 2.

As it could bee seen in Fig. 4. the open circuit potential decreased upon addition of citrate ions, indicating formation of complexes with zinc ions in the solution. Comparing the values of exchange current densities, obtained from polarization curves, to corrosion current densities, obtained from the mass lost, it could be concluded that zinc deposition and dissolution was dominant reaction and that corrosion of zinc proceeded slower for more than an order of magnitude. Based on above results it could be concluded that zinc, could be considered as potential anodic material in secondary electrochemical power source based on PANI cathode.

\section{Conclusion}

It could be concluded that magnesium, aluminum and zinc were liable to corrosion in chloride and chloride/citrate electrolytes investigated electrolytes. Based on the values of the corrosion potential of magnesium of $-1.889 \mathrm{~V}$ (SHE) in chloride and $-1.724 \mathrm{~V}$ (SHE) in chloride/citrate electrolyte, corrosion process of magnesium in chloride and chloride/citrate solutions could be explained by anodic dissolution of magnesium and cathodic hydrogen evolution. Due to very low corrosion potential, magnesium might be considered as potentially good anodic material for activated primary electrochemical power sources.

Aluminum, comparing to magnesium and zinc, had lowest values of the corrosion current density of around $1 \mu \mathrm{A} \mathrm{cm}^{-2}$ and highest value of the corrosion potential of around $-0.45 \mathrm{~V}$ (SHE) in both chloride and chloride/citrate solutions. It could be concluded that aluminum was in its passive state $\left(\mathrm{Al}_{2} \mathrm{O}_{3}\right)$ at corrosion potential. Owing to the relatively high value of the corrosion potential, cathodic reaction could be oxygen evolution reaction. According to the value of the corrosion potential in investigated electrolytes, aluminum is not challengeable anodic material for primary electrochemical power source.

Corrosion potential of zinc in both chloride and chloride/citrate electrolyte were similar $\sim-0.88 \mathrm{~V}$ (SHE), corrosion current density in chloride/citrate electrolyte was for almost one order of magnitude grater than in citrate electrolyte and it could be probably connected to influence of citrate ions on mechanism of zinc dissolution. It could be concluded that zinc was between stable metallic state and corrosion with formation of $\mathrm{Zn}^{2+}$. For current densities of practical interest, potential of the zinc electrodes were around -1.05 and $1.0 \mathrm{~V}$ (SCE), meaning that zinc could be considered as anodic material in primary electrochemical power sources based on PANI cathode. It was also concluded that zinc could be considered as anodic material in secondary electrochemical power sources, since in zinc containing electrolyte zinc deposition and dissolution was dominant reaction.

\section{Acknowledgment}

This work is financially supported by the Ministry of Science, Republic of Serbia, No. 142044.

\section{References}

[1] Sima M, Visan T, Buda M. A comparative study of zinc-polyaniline electrochemical cells having sulfate and chloride electrolytes. J Power Sources 1995;56:133-6.

[2] Kan J, Xue H, Mu S. Effect of inhibitors on Zn-dendrite formation for zincpolyaniline secondary battery. J Power Sources 1998;74:113-6.

[3] Rahmanifar SM, Mousavi FM, Shamsipur M, Ghaemia M. What is the limiting factor of the cycle-life of $\mathrm{Zn}$-polyaniline rechargeable batteries. J Power Sources 2004;132:296-301.

[4] Karami H, Mousavi FM, Shamsipur M. A new design for dry polyaniline rechargeable batteries. J Power Sources 2003;117:255-9.

[5] Rahmanifar SM, Mousavi FM, Shamsipur M, Heli H. A study on open circuit voltage reduction as a main drawback of $\mathrm{Zn}$-polyaniline rechargeable batteries. Synth Met 2005;155:480-4.

[6] Mirmohseni A, Solhjo R. Preparation and characterization of aqueous polyaniline battery using a modified polyaniline electrode. Eur Polym J 2003;39:219-23.

[7] Rüetschi P. Energy storage and the environment: the role of battery technology. J Power Sources 1993;42:1-7.

[8] Beck F, Rüetschi P. Rechargeable batteries with aqueous electrolytes Electrochim Acta 2000;45:2467-82.

[9] Kumar G, Sivashanmugam A, Muniyandi N, Dhawan SK, Trivedi DC. Polyaniline as an electrode material for magnesium reserve battery. Synth Met 1996;80:279-82.

[10] Li Q, Bjerrum NJ. Aluminum as anode for energy storage and conversion: a review. J Power Sources 2002;110:1-10.

[11] Heise WG, Schumcher AE, Cahoon CN. A heavy duty chlorine-depolarized cell. J Electrochem Soc 1948;94:99-105.

[12] Zaromb S. The use of aluminum anodes in alkaline primary batteries. J Electrochem Soc 1962;109:1125-30.

[13] Bockstie D, Trevethan L, Zaromb S. Control of Al corrosion in caustic solutions. J Electrochem Soc 1963;110:267-71.

[14] Kitani A, Kaya M, Saski K. Performance study of aqueous polyaniline batteries. J Electrochem Soc 1986;133:1069-72.

[15] Trinidad F, Montemayor CM, Fatas E. Performance study of zinc/zinc dichloride, ammonium chloride/polyaniline/carbon battery. J Electrochem Soc 1991;138:3186-91.

[16] Gospodinova N, Terlemeyan L. Conducting polymers prepared by oxidative polymerization: polyaniline. Prog Polym Sci 1998;23:1443-84.

[17] Megnoli G, Musiani MM, Pletcher D, Valcher S. Studies of $\mathrm{Zn} / \mathrm{ZnX}_{2} /$ polyaniline batteries. J Appl Electrochem 1987;17:525-31.

[18] Jugović BZ, Trišović TLj, Stevanović J, Maksimović M, Grgur BN. Novel electrolyte for zinc-polyaniline batteries. J Power Sources 2006;160:1447-50.

[19] Jugović BZ, Trišović TLj, Stevanović J, Maksimović M, Grgur BN. Comparative studies of chloride and chloride/citrate based electrolytes for zinc-polyaniline batteries. Electrochim Acta 2006;51:6268-74.

[20] Pourbaix M. Atlas of electrochemical equillibria in aqueous solutions. 2nd English ed. Houston: NACE and Brussels, CEBEL; 1974 